Economic and Environmental Geology

Research Paper

\title{
Genetic Environments of Au-Ag-bearing Geumhwa Hydrothermal Vein Deposit
}

\author{
Sunjin Lee, Sang-Hoon Choi ${ }^{*}$ \\ Department of Earth and Environmental Sciences, Chungbuk National University, Cheongju 28644, Korea \\ *Corresponding author : cshoon@cbnu.ac.kr
}

\section{ARTICLE INFORMATION}

Manuscript received 18 January 2021

Received in revised form 21 January 2021

Manuscript accepted 21 January 2021

Available online 26 February 2021

DOI : http://dx.doi.org/10.9719/EEG.2021.54.1.49

\section{Research Highlights}

- The Geumhwa hydrothermal Au-Ag deposit is located within the Cretaceous Gyeongsang basin.

- The hydrothermal system formed by progressive mixing of magmatic and/or equilibrated meteoric hydrothermal fluids with meteoric groundwater.

- The deposit may represent a vein system transitional between porphyry- and epithermal-type.

\begin{abstract}
The Geumhwa Au-Ag deposit is located within the Cretaceous Gyeongsang basin. Mineral paragenesis can be divided into two stages (stage I and II) by major tectonic fracturing. Stage II is economically barren. Stage I, at which the precipitation of major ore minerals occurred, is further divided into three substages(early, middle and late) with paragenetic time based on minor fractures and discernible mineral assemblages: early substage, marked by deposition of pyrite with minor wolframite; middle substage, characterized by introduction of electrum and base-metal sulfides with $\mathrm{Cu}-\mathrm{As}$ and/or $\mathrm{Cu}-\mathrm{Sb}$ sulfosalts; late substage, marked by hematite and $\mathrm{Bi}$ sulfosalts with secondary minerals. Changes in vein mineralogy reflect decreases in temperature and sulfur fugacity with a concomitant increase in oxygen fugacity. Fluid inclusion data indicate progressive decreases in temperature and salinity within each substage with increasing paragenetic time. During the early portion of stage I, high-temperature $\left(\geq 410^{\circ} \mathrm{C}\right)$, high-salinity fluids (up to $\approx 44$ equiv. wt. \% NaCl) formed by condensation during decompression of a magmatic vapor phase. During waning of early substage, high-temperature, high-salinity fluids gave way to progressively cooler, more dilute fluids associated with main Au-Ag mineralization (middle) and finally to $\approx 180^{\circ} \mathrm{C}$ and $\geq 0.7$ equiv. wt. $\% \mathrm{NaCl}$ fluids associated with hematite and sulfosalts ( \pm secondary) mineralization (late substage). These trends are interpreted to indicate progressive mixing of high- and medium to low-salinity hydrothermal fluids with cooler, more dilute, oxidizing meteoric waters. The Geumhwa Au-Ag deposit may represent a vein-type system transitional between porphyry-type and epithermal-type.
\end{abstract}

Keywords : Geumhwa Au-Ag deposit, hydrothermal, fluid inclusion, vein deposits, halite

Citation: Lee, S., Choi, S.-H. (2021) Genetic Environments of Au-Ag-bearing Geumhwa Hydrothermal Vein Deposit, v.54, p.49-60, doi:10.9719/EEG2021.54.1.49.

This is an Open Access article distributed under the terms of the Creative Commons Attribution Non-Commercial License (http://creativecommons.org/ licenses/by-nc/3.0) which permits unrestricted non-commercial use, distribution, and reproduction in any medium, provided original work is properly cited. pISSN 1225-7281; eISSN 2288-7962/@2021 The KSEEG. Printed by Hanrimwon Publishing Company. All rights reserved. 


\section{연구논문}

\section{함 금-은 금화 열수 맥상광상의 생성환경}

이선진 · 최상훈*

충북대학교 지구환경과학과

*책임저자 : cshoon@cbnu.ac.kr

\section{요 약}

금화광상은 백악기 경상퇴적분지 내에 분포하는 진주층 퇴적암 내에 발달한 열극을 충진하여 생성된 함 금-은 열수 맥상광상 으로, 괴상, 각력상 및 호상 및 정동 조직 등 복합적인 조직적 특성을 보여준다. 금화광상 맥상 광화작용은 지구조적 운동(tectonic break)에 의하여 광화 1 기(stage I)와 광화 2기(stage II)로 구분된다. 광화 1기는 금-은 광화작용이 진행된 주 광화시기로, 석영 맥 내에 주된 함 금·은 광물인 에렉트럼과 함께 황화광물, 산화광물 및 황염광물 등이 산출한다. 광화 2기는 주 광화작용 이후 금속 광화작용이 이루어지지 않은 방해석맥의 생성 시기이다. 광화 1 기는 광물 광생관계와 산출하는 광물 조합 특성 등에 의하 여 3 개의 세부 광화시기(초기, 중기, 후기)로 구분된다. 광화 1 기의 초기에는 주로 황철석, 황동석 등의 황화광물이 철망간중석, 자철석 등의 산화광물을 수반하여 산출한다. 광화 1 기 중기는 주된 금·은 광화작용이 광화 1 기의 초기 말부터 계속하여 진행된 시기이다. 주로 에렉트럼과 함께 황동석, 섬아연석 등의 황화광물과 자철석 등의 산화광물이 산출되며, 텐난타이트 및 테트라히 드라이트 등의 황염광물이 소량 수반되어 산출된다. 광화 1 기 후기에는 방연석, 적철석과 함께 소량의 함 비스무스 황염광물이 산출하며 풍화작용 관련 이차광물의 생성이 진행되었다.

금화광상 광물 공생관계 변화는 열수계의 온도와 황 분압 조건의 감소 및 이에 수반된 산소 분압 조건의 증가 등의 환경변화가 반영된 결과이다. 유체포유물 실험.연구 결과를 종합하면, 초기 금화 열수계는 $\geq 410^{\circ} \mathrm{C}$ 온도 조건에서 하부 마그마로부터 용리 된 고 염농도 $(\geq 44 \mathrm{wt} . \% \mathrm{NaCl})$ 를 갖는 유체와 금화광상 생성 심도 하부까지 순환하여 물-암석 반응이 진행된 천수 기원의 중 내지 저 염농도 $(\approx 7.0 \mathrm{wt} . \% \mathrm{NaCl})$ 의 열수가 함께 유입되어 형성되었다. 그 이후 금화 열수계는 유체의 냉각, 비등작용 및 천수 혼입 등에 의하여 진화되었으며, 이들 진화기구에 수반된 냉각작용 및 화학성 변화 등에 의하여 온도 감소 $\left(\leq 200^{\circ} \mathrm{C}\right)$ 와 염농도 변화 $(\leq 1.0$ equiv. wt. \% NaCl)가 야기되었다. 이러한 금화 열수계의 형성 및 진화 특성은 함 금-은 열수 맥상광상인 금화광상이 초기 천부 관입 마그마의 영향으로 마그마 우세 열수계로 부터 광화 후기 천수의 유입이 우세해지는 천열수계로 변환되는 점 이적인 생성환경에서 생성된 맥상광상임을 지시한다.

주요어 : 금화 금-은 광상, 열수, 유체포유물, 맥상광상, 암염

\section{1. 서 론}

인간이 필요성에 의하여 사용하는 지구의 자원은 광물 자원, 에너지자원, 토양자원, 수자원 등으로 대분된다. 이 들 지구의 자원은 인간의 시간 단위와 자원 생성(충전)시 간 단위의 개념 차이에 의하여 재생성자원(renewable resources)과 비재생성자원(nonrenewable resources)으로 구분된다. 재생성자원이란 인간의 시간 개념 내에서 재 생성·재충전되는 자원으로서, 적절한 관리하에서 소비가 이루어진다면 고갈에 대한 우려가 없는 자원을 의미한다. 비재생성자원은 인간의 시간 개념 내에서 재생성·재충전 되지 않는 자원으로서, 적절한 관리하에서 소비가 이루 어져도 일정 기간 내에는 재생성·재충전되지 않아 고갈 에 대비하여야 하는 자원이다. 광물자원과 에너지자원은 비재생성자원으로 취급되며, 이러한 이유로 그 양에 한 계가 있어 고갈에 대비하여야 한다. 한편, 지화학계를 적
용하면 지구는 폐쇄계(closed system)에 해당하여 지구 외 부로부터 물질의 유입이 이루어질 수 없다. 따라서 우리 인간은 지구에서 생성되어 부존된 지구 물질인 지구의 자원만으로 끝없이 발전하는 문명사회를 유지하여야 한다. 예로부터 한반도는 금, 은, 중석, 동 등 일부 광물자원 의 보고로 알려져 왔으나, 근래 국내 자본에 의한 국내 에서의 탐사 또는 개발 활동은 거의 없는 상황이다. 그 러나 근래 외국의 자원탐사회사에서 광상의 유체진화 특 성 연구 및 이에 기인한 광석광물의 지화학적 특성 변화 등의 연구 결과에 근거한 활발한 탐사 활동을 수행한 바 있으며, 이 결과 일부 지역에서 대규모 광체 부존이 확 인되는 등 적극적인 광상 성인에 대한 기초연구와 이를 근거로 하는 탐사 노력의 중대성을 일깨운 바 있다. 결 국, 국내에 부존하는 광물자원에 대한 광량 확보는 광상 학적 연구를 통하여 정립된 유형별 또는 광상(또는 광화 대)별 성인 연구와 이에 근거한 광상 성인 모델을 활용 
함으로 가능하며, 이를 기반으로 해외 광물자원 탐사·개 발 프로젝트도 성공적으로 수행할 수 있을 것이다.

국내에 부존하는 금·은 광상은 한반도 전역에 걸쳐 수 백여 개의 광상이 광범위하게 분포하고 있다. 이들 금·은 광상들은 성인적으로 열수 맥상광상, 열수 교대광상, 스 카른광상, 알라스카이트광상 및 퇴적광상인 사금광상 등 의 유형으로 분류되지만, 중요한 금·은 광상들의 대부분 은 열수 맥상광상에 속한다. 국내 함 금-은 열수 맥상광 상들은 대부분 한반도 대표적인 화성활동인 쥬라기 대보 화성활동(183-121Ma) 및 백악기 불국사 화성활동(110$60 \mathrm{Ma}$ )과 상당히 밀접한 연관성을 보이며 서로 다른 광 상·지질학적 특성을 보여준다. 이들 두 시기 화성활동과 관련된 관입암체의 관입·정체 심도는 상당한 차이를 보 이는데, 쥬라기 관입암체의 관입·정체 심도는 $\geq 5 \mathrm{~km}$, 백 악기 관입암체의 관입·정체 심도는 $\leq 2-3 \mathrm{~km}$ 로 보고된 바 있다(Tsusue et al., 1981; Cho and Kwon, 1994). 이러한 관입·정체 심도의 차이는 관계화성암과 관련된 금·은 광 화작용의 특성이 광상 형성 당시의 심도와 관련된 열수 계의 진화과정에서 다양한 물리·화학적 금·은의 침전환 경에 지대한 영향을 준 것으로 사료된다. 이들 국내 함 금·은 열수 맥상광상들은 물리·화학적 생성환경의 차이 에 기인하여 중열수 광상(태창, 보련광상 등), 한국형 광 상(천보, 일보, 대흥, 전의광상 등), 천열수 광상(전주일, 통영광상 등)으로 분류된다(Shelton et al., 1988). 또한, 한반도 내 함 금·은 열수 맥상광상들은 금·은 생산량 비, 광석 내 금·은 함량비 및 산출 광물의 공생관계와 광물 학적 특성 등에 의하여 Group I(자류철석형 금광상), Groups $\mathrm{IIA}, \mathrm{IIB}$ (황철석형 금광상), Group III(휘은석형 금은광상), Group IV(안티몬형 금은광상), 및 Group V(안티몬형 은 광상)의 6가지 유형으로 분류되며(Lee et al., 2007), 동일 한 유형의 열수 맥상광상에서도 성인적 차이점이 도출된 바 있다.

본 연구는 금화 금-은 광상의 광화작용과 관련된 광석 광물의 산출상태, 광물학적 특성, 광물 공생관계, 열역학 적 자료에 근거한 광석광물의 침전환경 및 광화유체의 특성과 진화과정 등을 밝히고, 이를 근거로 광상 생성 시 의 지배적인 물리·화학적 요인과 부존 특성 등을 규명하 여 추가 탐사 및 재개발 등에 활용 가능한 광상학적 지 침자료를 제시하고자 한다.

\section{2. 지질개요}

금화광상은 한반도 남동부에 위치하는 경상퇴적분지 내 북서부에 위치한다(Fig. 1). 경상퇴적분지에는 경상누 층군에 해당하는 퇴적·화산암류가 전역에 분포하고 있으
며, 백악기 불국사 화강암류와 중·산성 암맥이 이들을 관 입 산출한다. 경상누층군은 하부로부터 신동층군, 하양층 군 및 최상부 유천층군으로 구분된다(Chang, 1975; Kang and Paik, 2012).

금화광상의 주변 지역에는 신동층군의 낙동층, 하산동 층, 진주층, 하양층군의 하부층에 해당하는 칠곡층 등의 퇴적암류와 유천층군 화산암류 및 이들을 관입한 불국사 화성암류인 팔공산 화강암 등이 분포한다(Fig. 1). 지역 내 신동층군 퇴적암류는 팔공산 화강암과의 접촉부에서 광역적으로 혼펠스화 되어있다(Fig. 1).

낙동층은 지역 내 가장 하부에 해당하는 지층으로, 지 역 서북부 일부에 분포한다. 낙동층은 주로 함력사암 및 역암과 이암으로 구성되며, 부분적으로 흑색 셰일과 탄 질셰일이 협재 되어 산출한다. 하산동층은 낙동층을 정 합으로 피복하여 산출하며, 지역 내 서편에 남북방향으 로 분포하고 있다. 하산동층은 주로 적색의 세립질 이암 으로 구성되며, 역암 및 사암 등이 호층으로 협재되어 산 출한다(Kim et al., 1981). 진주층은 신동층군 최상부 지 층으로, 대율지구 서편과 중앙부에 남북방향으로 넓게 분 포 산출한다(Fig. 1). 진주층은 주로 사암, 흑색 이암 및 셰일로 구성된다(Kim et al., 1981).

칠곡층은 지역 내 북동부에 분포하며, 하부의 진주층 과 정합 관계를 보이며 산출한다. (Kim et al., 1981).

광상지역 서편에 부분적으로 분포하는 유천층군 유문 암질 응회암은 하부 퇴적암층을 부정합으로 피복 산출한 다(Fig. 1). 불국사 화성활동에 의하여 분화한 팔공산 화 강암은 지역 내 동남부와 서남부에 산출 분포한다(Fig. 1). 팔공산 화강암은 주로 흑운모 또는 흑운모-각섬석 화강 암이다(Hong, 1983; Choe and Jwa, 2004).

\section{3. 광상}

금화광상은 주로 진주층 퇴적암 내에 발달한 열극을 충 진하여 생성된 함 금-은 맥상광상으로, 괴상, 각력상 및 호상조직과 함께 정동의 발달 등을 수반한 복합 석영맥 조직의 특성을 보여준다. 금화광상은 주로 $\mathrm{N} 5 \sim 35^{\circ} \mathrm{W}$ (경 사 $70 \sim 85^{\circ} \mathrm{NE}$ )의 방향성을 갖는 4 개 조의 석영맥(본맥, 양지맥, 모래맥, 남원맥)으로 구성되어 있다. 금화 함 금 -은 석영맥은 일반적으로 $\leq 1 \sim 5 \mathrm{~cm}$ 의 맥폭을 갖는 세맥 형태로 확인되며, 부분적으로 맥의 합류 지점에서는 약 $20 \mathrm{~cm}$ 까지 맥폭이 증가하기도 한다(Fig. 2). 금화광상 함 금-은 석영맥의 연장은 주향 방향을 따라 약 $1,000 \mathrm{~m}$ 정 도 이상으로 추정되며, 갱내에서 확인된 연장은 약 $500 \mathrm{~m}$ 정도이다.

입항이 가능한 금화광상 본맥(5호갱, 6 호갱)과 양지맥 


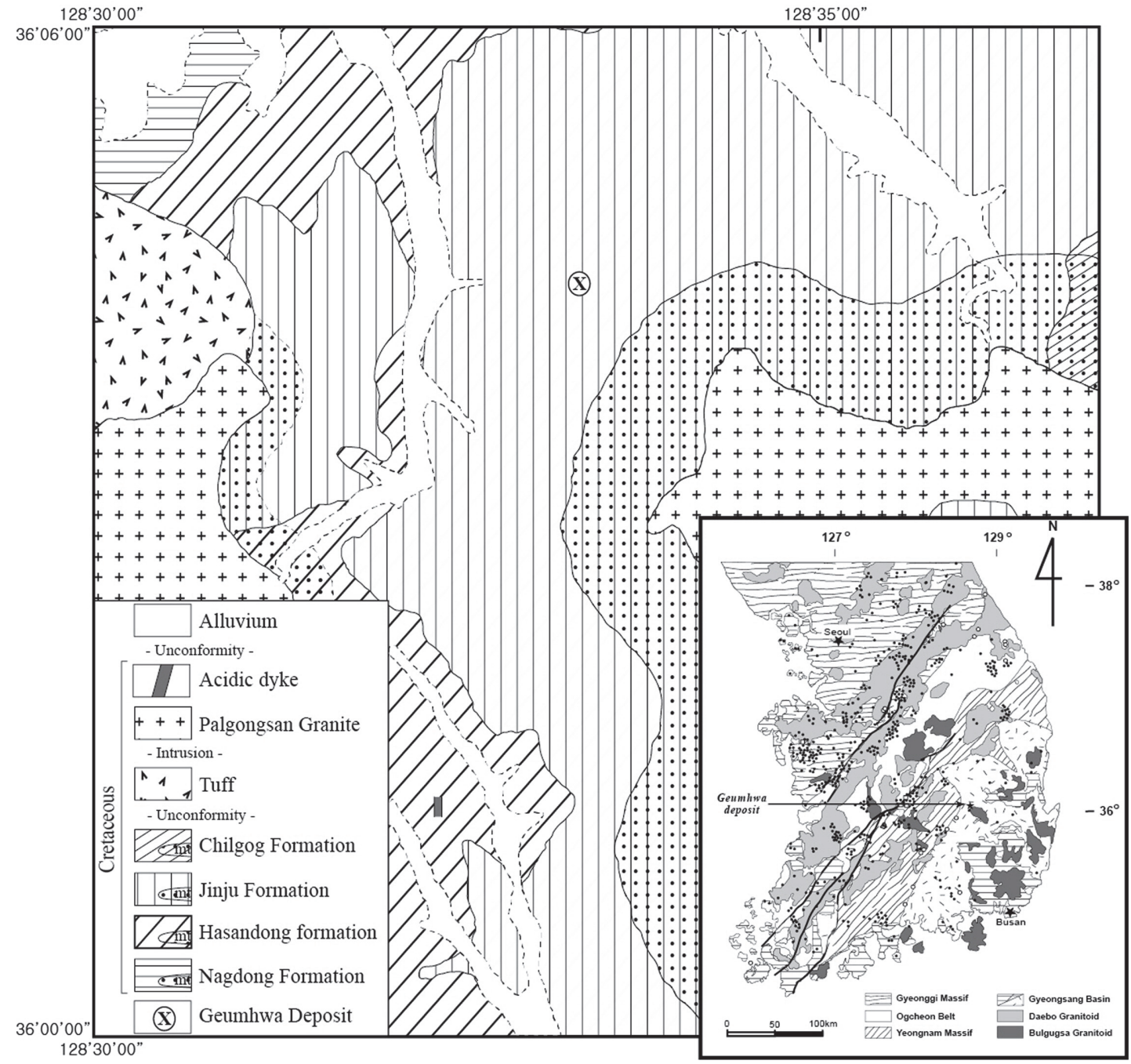

Fig. 1. Geologic map of the Geumhwa deposit area (after Kim et al., 1981). Simplified geologic map of Korea shows the location of the Geumhwa deposit.
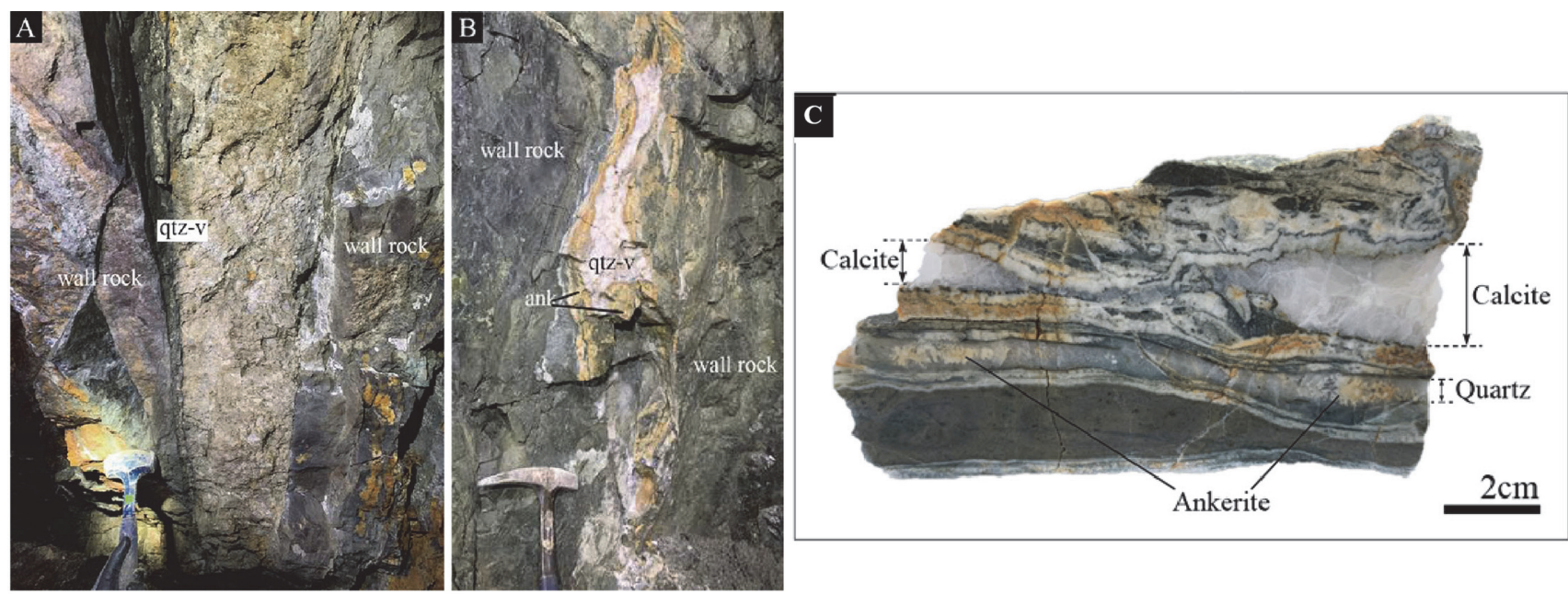

Fig. 2. Photographs of the Au-Ag bearing hydrothermal vein outcrops (A and $\mathrm{B})$ and the products of hydrothermal mineralization (C) at the Geumhwa deposit. Abbreviations: ank=ankerite, qtz-v or Quartz=quartz vein, Calcite $=$ calcite vein. 
(3호갱) 갱내 석영맥 내에는 괴상의 황철석과 황동석이 관찰되며, 부분적으로 섬아연석 및 방연석이 수반되어 산 출한다. 석영맥 내에는 부분적으로 초기 맥상 광물로서 전기석군(tourmaline group) 길전기석(dravite)의 산출이 관찰된다. 이외에 함 동 광물의 2차 산화광물인 공작석 (malachite)과 남동석(azurite)이 석영맥을 부분적으로 피 복 하여 산출된다.

\section{4. 광물 및 공생관계}

금화광상의 맥상 광화작용은 지구조적 운동(tectonic break)에 의하여 광화 1기(stage I)와 광화 2기(stage II)로 구분된다(Fig. 3). 광화 1기는 함 금-은 광화작용이 진행 된 주 광화시기로, 석영맥 내에 주된 함 금·은 광물인 에 렉트럼(electrum)과 함께 황화광물, 산화광물 및 황염광 물 등이 산출한다. 광화 2 기는 주 광화작용 이후 금속 광 화작용이 이루어지지 않은 방해석맥의 생성 시기이다(Fig. 3).

광화 1 기: 광화 1 기는 광물 광생관계와 산출하는 광물 조합 특성 등에 의하여 3개의 세부 광화시기(초기, 중기, 후기)로 구분된다(Fig. 3). 금화광상 광화 1기의 초기에는 주로 황철석, 황동석 등의 황화광물이 철망간중석, 자철

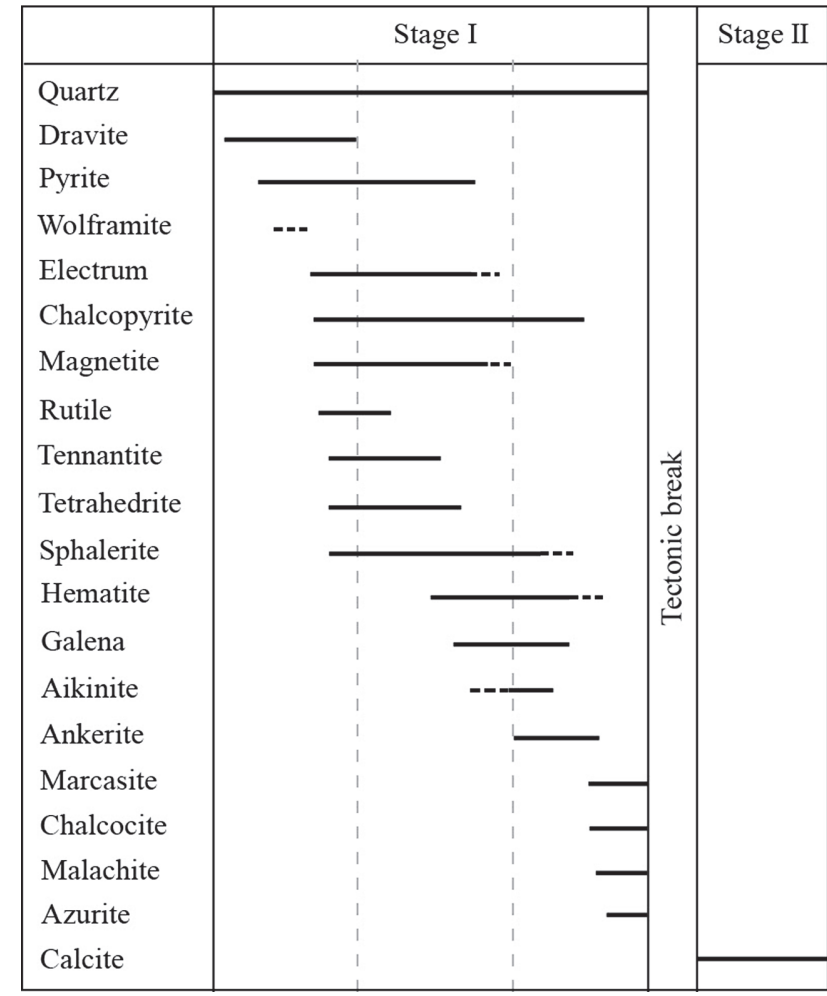

Fig. 3. Vein mineral paragenesis of the Geumhwa Au-Ag deposit.

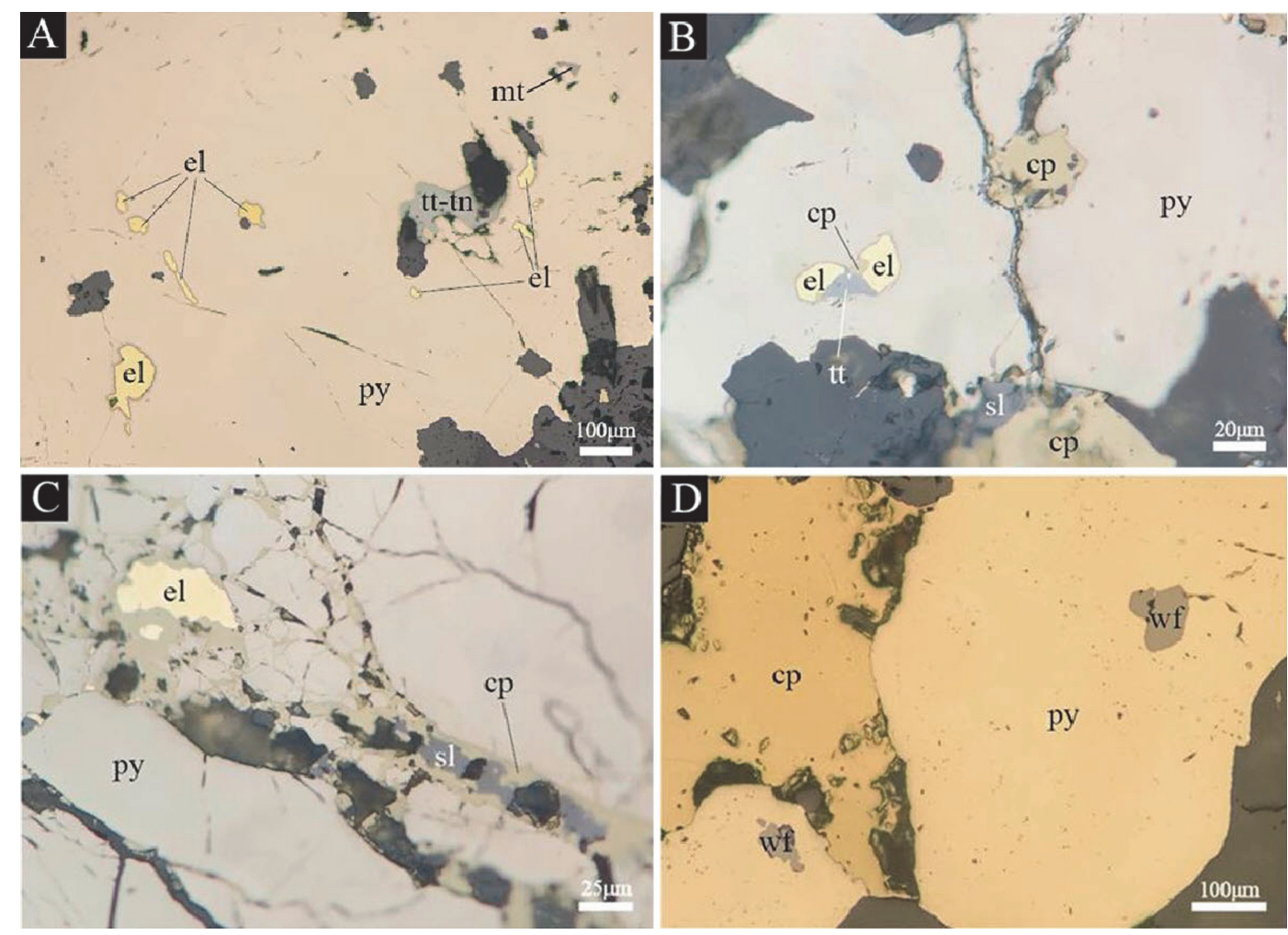

Fig. 4. Photomicrographs of mineral occurrence and assemblages at the Geumhwa deposit. Irregular electrum grain in pyrite (A and B) or within chalcopyrite (C). Subhedral tetrahedrite (and/or) tennantite in pyrite (A and B). Subhedral wolframite in early pyrite grain (D). Abbreviations: $\mathrm{cp}=$ chalcopyrite, el=electrum, $\mathrm{mt}=$ magnetite, $\mathrm{py}=$ pyrite, $\mathrm{sl}=$ sphalerite, $\mathrm{tn}=$ tennantite, $\mathrm{tt}=$ tetrahedrite, $\mathrm{wf}=\mathrm{wolframite}$. 
석 등의 산화광물을 수반하여 산출한다. 광화 1 기 중기 는 주된 금·은 광화작용이 광화 1 기의 초기 말부터 계속 하여 진행된 시기이다. 주로 에렉트럼과 함께 황동석, 섬 아연석 등의 황화광물과 자철석 등의 산화광물이 산출되 며, 비사면동석(tennantite) 및 사면동석(tetrahedrite) 등의 황염광물이 소량 수반되어 산출된다(Figs. $4 \mathrm{~A}$ and $4 \mathrm{~B}$ ). 광화 1 기의 후기에는 방연석과 함께 함 비스무스 $(\mathrm{Bi})$ 황 염광물인 아이키나이트(Aikinite) 및 산화광물인 적철석 등이 수반 산출된다. 광화 1 기 광화작용 최후기에는 풍 화작용으로 인한 이차광물의 생성이 진행되어, 함 동 광 물의 2 차 광물인 공작석과 남동석 및 황철석의 풍화산물 인 백철석이 상기 황화광물의 균열부 및 입자 주변부를 따라 교대하여 산출한다(Fig. 3).

광화 1 기의 황철석은 주로 세립 내지 조립상의 타형으 로 산출되며, 부분적으로 괴상으로 산출하거나 석영맥 내 산점상으로 산출한다. 괴상으로 산출하는 황철석은 철망 간중석, 황동석, 에렉트럼, 비사면동석, 사면동석 및 자철 석을 내부에 포획하거나 공생관계를 이루며 산출한다. 일 부 황철석은 입자 외곽부 또는 균열부를 따라 풍화작용 에 의하여 2 차 광물인 백철석으로 교대된다.

철망간중석은 주로 괴상의 황철석 내부에 포획되거나 맥상 석영 내 균열부를 따라 세립상으로 산출한다(Fig. 4D).

금화광상의 주된 함 금·은 광석광물인 에렉트럼은 광 화 1 기 초기의 말기부터 광화 1 기 중기에 걸쳐 주로 침 전이 이루어진 것으로 확인된다. 광화 초기 에렉트럼은 주로 괴상 및 자형의 황철석 내부의 균열부를 충진하거 나 황동석 내부에 포획되어 산출되며, 광화 중기 에렉트 럼은 주로 괴상의 황동석과 용리 조직을 이루어 산출한 다. 금화광상 에렉트럼은 98 56 atomic \% Au의 조성을 보이며(Table 1), 초기에서 중기로 광화 1기 광화작용이 진행됨에 따라 $\mathrm{Au}$ 의 함량은 감소하는 것으로 확인되었다.

황동석은 주로 자형의 황철석을 교대하여 괴상으로 산 출하거나, 황철석의 균열부를 충진하여 산출된다. 괴상의 황동석 내부에는 에렉트럼, 금홍석, 비사면동석 및 사면 동석 등이 공생관계를 보이거나 포획되어 산출한다.

자철석은 맥상 석영 및 초기 괴상의 황철석 내부 균열 부를 충진 또는 교대하여 산출한다(Fig. 4A).

비사면동석은 주로 괴상의 황철석 및 황동석의 균열부 를 타형으로 충진하여 산출한다. 사면동석은 주로 괴상 의 황동석 내에 포획되거나 균열부를 충진·교대하여 산 출한다. 일부 사면동석은 황철석 및 섬아연석 내 균열부 를 충진하여 산출한다(Figs. $4 \mathrm{~A}$ and $4 \mathrm{~B}$ ).

섬아연석은 주로 광화 1 기의 중기 광화작용 동안 침전 하였으며, 황동석의 내부 균열부를 따라 충진하거나 공 생관계를 보이면서 반자형 내지 타형으로 산출된다(Figs. 4B
Table 1. Chemical composition of electrum from Geumhwa deposit

\begin{tabular}{|c|c|c|c|c|c|c|}
\hline \multirow{2}{*}{$\begin{array}{c}\text { Sample } \\
\text { No. }\end{array}$} & \multicolumn{3}{|c|}{ Weight \% } & \multicolumn{3}{|c|}{ Atomic $\%$} \\
\hline & $\mathrm{Au}$ & $\mathrm{Ag}$ & Total & $\mathrm{Au}$ & $\mathrm{Ag}$ & $\mathrm{Ag} / \mathrm{Au}$ \\
\hline \multirow[t]{12}{*}{ G6-11-1 } & 82.03 & 19.04 & 101.07 & 70.24 & 29.76 & 0.42 \\
\hline & 79.39 & 20.71 & 100.10 & 67.73 & 32.27 & 0.48 \\
\hline & 79.05 & 21.11 & 100.16 & 67.23 & 32.77 & 0.49 \\
\hline & 82.97 & 17.50 & 100.47 & 72.20 & 27.80 & 0.39 \\
\hline & 81.99 & 18.31 & 100.30 & 71.03 & 28.97 & 0.41 \\
\hline & 82.18 & 18.33 & 100.51 & 71.06 & 28.94 & 0.41 \\
\hline & 79.03 & 19.78 & 98.81 & 68.64 & 31.36 & 0.46 \\
\hline & 80.04 & 20.41 & 100.45 & 68.23 & 31.77 & 0.47 \\
\hline & 77.20 & 21.97 & 99.16 & 65.81 & 34.19 & 0.52 \\
\hline & 72.84 & 26.95 & 99.79 & 59.68 & 40.32 & 0.68 \\
\hline & 72.22 & 28.76 & 100.98 & 57.90 & 42.10 & 0.73 \\
\hline & 92.18 & 9.20 & 101.38 & 84.59 & 15.41 & 0.18 \\
\hline \multirow[t]{7}{*}{ G6-11-2 } & 81.86 & 17.07 & 98.93 & 72.42 & 27.58 & 0.38 \\
\hline & 87.56 & 12.41 & 99.97 & 79.44 & 20.56 & 0.26 \\
\hline & 86.78 & 12.82 & 99.59 & 78.76 & 21.24 & 0.27 \\
\hline & 85.82 & 12.75 & 98.57 & 78.66 & 21.34 & 0.27 \\
\hline & 86.44 & 12.71 & 99.15 & 78.83 & 21.17 & 0.27 \\
\hline & 88.44 & 11.40 & 99.84 & 80.95 & 19.05 & 0.24 \\
\hline & 99.90 & 1.30 & 101.20 & 97.68 & 2.32 & 0.02 \\
\hline \multirow[t]{8}{*}{ G6-11-3 } & 83.65 & 17.90 & 101.55 & 71.91 & 28.09 & 0.39 \\
\hline & 82.79 & 18.35 & 101.15 & 71.19 & 28.81 & 0.40 \\
\hline & 81.48 & 19.70 & 101.18 & 69.37 & 30.63 & 0.44 \\
\hline & 81.52 & 18.19 & 99.71 & 71.05 & 28.95 & 0.41 \\
\hline & 80.54 & 18.61 & 99.16 & 70.32 & 29.68 & 0.42 \\
\hline & 81.87 & 18.66 & 100.53 & 70.61 & 29.39 & 0.42 \\
\hline & 76.60 & 21.85 & 98.45 & 65.75 & 34.25 & 0.52 \\
\hline & 90.62 & 10.43 & 101.05 & 82.63 & 17.37 & 0.21 \\
\hline \multirow[t]{4}{*}{ G6-7-2 } & 84.19 & 14.80 & 99.00 & 75.70 & 24.30 & 0.32 \\
\hline & 88.78 & 10.16 & 98.94 & 82.71 & 17.29 & 0.21 \\
\hline & 90.00 & 9.61 & 99.60 & 83.69 & 16.31 & 0.19 \\
\hline & 87.23 & 12.56 & 99.80 & 79.18 & 20.82 & 0.26 \\
\hline \multirow[t]{2}{*}{ G6-6-2 } & 73.13 & 26.45 & 99.58 & 60.22 & 39.78 & 0.66 \\
\hline & 73.57 & 26.85 & 100.42 & 60.01 & 39.99 & 0.67 \\
\hline G6-6-1 & 72.35 & 25.05 & 97.40 & 61.27 & 38.73 & 0.63 \\
\hline
\end{tabular}

and $4 \mathrm{C}$ ). 섬아연석은 $4.5 \sim 0.1$ mole $\% \mathrm{FeS}$ 의 조성 특성을 보여주며(Table 2), 후기로 가면서 $\mathrm{FeS}$ 함량은 감소하는 경향성을 보여준다. 광물입자 내 누대구조 등에 의한 함 량변화는 확인되지 않는다.

적철석은 주로 괴상의 자철석 내부 균열부를 따라 충 진하거나, 자철석과 용리 조직을 보이며 산출하며, 부분 적으로 후기 맥상 석영에 수반되어 자형으로 침전한 것 
Table 2. Chemical composition of sphalerite from Geumhwa deposit

\begin{tabular}{|c|c|c|c|c|c|c|c|c|c|}
\hline \multirow{2}{*}{$\begin{array}{c}\text { Sample } \\
\text { No. }\end{array}$} & \multicolumn{5}{|c|}{ Weight $\%$} & \multicolumn{4}{|c|}{ Mole $\%$} \\
\hline & $\mathrm{Zn}$ & $\mathrm{Fe}$ & $\mathrm{Cd}$ & $\mathrm{S}$ & Total & $\mathrm{ZnS}$ & $\mathrm{FeS}$ & $\mathrm{CdS}$ & Total \\
\hline \multirow{11}{*}{ G6-11-1 } & 64.90 & 0.15 & 1.11 & 32.81 & 99.08 & 98.6 & 0.3 & 1.0 & 100.0 \\
\hline & 64.97 & 0.32 & 1.61 & 32.79 & 99.83 & 97.8 & 0.6 & 1.4 & 100.0 \\
\hline & 64.17 & 0.30 & 2.02 & 32.79 & 99.49 & 97.4 & 0.5 & 1.8 & 100.0 \\
\hline & 62.88 & 0.69 & 2.38 & 33.21 & 99.36 & 96.3 & 1.2 & 2.1 & 100.0 \\
\hline & 63.83 & 0.90 & 1.41 & 32.91 & 100.16 & 95.5 & 1.6 & 1.2 & 100.0 \\
\hline & 64.73 & 0.91 & 1.07 & 33.12 & 100.52 & 96.4 & 1.6 & 0.9 & 100.0 \\
\hline & 63.64 & 1.24 & 0.88 & 32.90 & 99.72 & 95.4 & 2.2 & 0.8 & 100.0 \\
\hline & 63.92 & 1.44 & 1.03 & 33.22 & 100.72 & 94.9 & 2.5 & 0.9 & 100.0 \\
\hline & 63.07 & 0.73 & 2.93 & 32.84 & 100.07 & 95.4 & 1.3 & 2.6 & 100.0 \\
\hline & 62.42 & 0.62 & 3.21 & 31.84 & 98.76 & 95.0 & 1.1 & 2.8 & 100.0 \\
\hline & 62.66 & 0.86 & 2.88 & 32.38 & 99.33 & 95.1 & 1.5 & 2.5 & 100.0 \\
\hline G6-11-2 & 60.63 & 0.91 & 2.36 & 32.40 & 97.11 & 94.9 & 1.7 & 2.2 & 100.0 \\
\hline \multirow{18}{*}{ G6-11-3 } & 63.47 & 1.59 & 1.28 & 33.21 & 100.48 & 94.7 & 2.8 & 1.1 & 100.0 \\
\hline & 62.40 & 1.27 & 1.29 & 32.75 & 98.38 & 95.5 & 2.3 & 1.1 & 100.0 \\
\hline & 62.85 & 1.73 & 1.36 & 33.01 & 99.99 & 94.2 & 3.0 & 1.2 & 100.0 \\
\hline & 63.29 & 1.05 & 1.33 & 32.64 & 99.00 & 95.9 & 1.9 & 1.2 & 100.0 \\
\hline & 63.44 & 1.00 & 2.03 & 32.91 & 99.91 & 95.6 & 1.8 & 1.8 & 100.0 \\
\hline & 64.14 & 0.84 & 1.13 & 33.53 & 100.04 & 96.9 & 1.5 & 1.0 & 100.0 \\
\hline & 63.18 & 1.40 & 1.76 & 33.65 & 100.76 & 94.8 & 2.5 & 1.5 & 100.0 \\
\hline & 63.22 & 1.22 & 1.63 & 33.51 & 100.43 & 95.1 & 2.2 & 1.4 & 100.0 \\
\hline & 63.71 & 1.41 & 1.20 & 33.10 & 99.88 & 95.8 & 2.5 & 1.0 & 100.0 \\
\hline & 63.43 & 1.38 & 1.33 & 32.91 & 99.67 & 95.5 & 2.4 & 1.2 & 100.0 \\
\hline & 62.90 & 1.38 & 2.53 & 33.66 & 100.80 & 94.8 & 2.4 & 2.2 & 100.0 \\
\hline & 63.05 & 1.91 & 1.58 & 32.71 & 99.45 & 94.9 & 3.4 & 1.4 & 100.0 \\
\hline & 64.17 & 0.98 & 1.13 & 32.98 & 99.88 & 96.3 & 1.7 & 1.0 & 100.0 \\
\hline & 63.92 & 0.92 & 1.03 & 32.37 & 98.83 & 96.6 & 1.6 & 0.9 & 100.0 \\
\hline & 63.82 & 0.86 & 1.38 & 32.78 & 99.32 & 96.5 & 1.5 & 1.2 & 100.0 \\
\hline & 62.63 & 0.92 & 1.04 & 32.33 & 97.52 & 96.5 & 1.7 & 0.9 & 100.0 \\
\hline & 62.56 & 1.13 & 1.43 & 32.71 & 99.09 & 94.8 & 2.0 & 1.3 & 100.0 \\
\hline & 62.63 & 1.08 & 1.91 & 32.79 & 99.26 & 95.1 & 1.9 & 1.7 & 100.0 \\
\hline \multirow[t]{6}{*}{ G6-7-2 } & 60.69 & 1.60 & 0.92 & 33.16 & 97.34 & 94.7 & 2.9 & 0.8 & 100.0 \\
\hline & 59.88 & 2.54 & 1.11 & 32.62 & 98.14 & 91.4 & 4.5 & 1.0 & 100.0 \\
\hline & 61.58 & 1.29 & 0.90 & 32.58 & 97.17 & 95.5 & 2.3 & 0.8 & 100.0 \\
\hline & 62.00 & 1.03 & 0.84 & 33.04 & 97.34 & 96.7 & 1.9 & 0.8 & 100.0 \\
\hline & 61.71 & 0.79 & 1.17 & 33.02 & 97.20 & 96.7 & 1.4 & 1.1 & 100.0 \\
\hline & 61.32 & 1.59 & 0.77 & 33.21 & 97.04 & 96.1 & 2.9 & 0.7 & 100.0 \\
\hline \multirow[t]{12}{*}{ G6-6-2 } & 63.26 & 0.32 & 1.01 & 32.78 & 97.63 & 98.1 & 0.6 & 0.9 & 100.0 \\
\hline & 65.35 & 0.27 & 1.65 & 33.00 & 100.47 & 97.8 & 0.5 & 1.4 & 100.0 \\
\hline & 64.13 & 0.28 & 1.26 & 32.87 & 98.64 & 98.2 & 0.5 & 1.1 & 100.0 \\
\hline & 64.19 & 0.34 & 0.90 & 33.40 & 99.23 & 98.0 & 0.6 & 0.8 & 100.0 \\
\hline & 64.44 & 0.34 & 1.66 & 32.93 & 99.58 & 97.6 & 0.6 & 1.5 & 100.0 \\
\hline & 64.43 & 0.17 & 0.88 & 33.25 & 98.90 & 98.6 & 0.3 & 0.8 & 100.0 \\
\hline & 64.33 & 0.15 & 1.30 & 33.09 & 99.09 & 98.2 & 0.3 & 1.2 & 100.0 \\
\hline & 64.22 & 0.36 & 1.51 & 33.17 & 99.56 & 97.6 & 0.6 & 1.3 & 100.0 \\
\hline & 63.84 & 0.30 & 1.41 & 33.16 & 98.99 & 97.8 & 0.5 & 1.3 & 100.0 \\
\hline & 64.18 & 0.22 & 1.24 & 32.89 & 98.68 & 98.3 & 0.4 & 1.1 & 100.0 \\
\hline & 63.92 & 0.21 & 1.37 & 32.99 & 98.73 & 98.0 & 0.4 & 1.2 & 100.0 \\
\hline & 65.28 & 0.20 & 0.73 & 33.00 & 99.34 & 98.8 & 0.4 & 0.6 & 100.0 \\
\hline \multirow[t]{9}{*}{ G6-6-1 } & 64.39 & 0.63 & 1.42 & 33.39 & 100.18 & 97.1 & 1.1 & 1.2 & 100.0 \\
\hline & 63.68 & 0.66 & 1.36 & 33.38 & 99.59 & 96.8 & 1.2 & 1.2 & 100.0 \\
\hline & 63.62 & 0.05 & 2.10 & 32.48 & 99.58 & 96.0 & 0.1 & 1.8 & 100.0 \\
\hline & 63.71 & 0.14 & 2.57 & 32.58 & 99.65 & 96.5 & 0.2 & 2.3 & 100.0 \\
\hline & 64.84 & 0.14 & 1.82 & 32.72 & 99.96 & 97.5 & 0.2 & 1.6 & 100.0 \\
\hline & 65.46 & 0.45 & 1.59 & 31.78 & 99.90 & 96.9 & 0.8 & 1.4 & 100.0 \\
\hline & 65.68 & 0.48 & 1.18 & 31.77 & 99.44 & 97.6 & 0.8 & 1.0 & 100.00 \\
\hline & 64.79 & 0.60 & 1.58 & 32.19 & 99.87 & 96.5 & 1.0 & 1.4 & 100.00 \\
\hline & 65.30 & 0.90 & 1.67 & 32.20 & 100.72 & 96.0 & 1.5 & 1.4 & 100.00 \\
\hline
\end{tabular}




\section{으로 확인된다.}

방연석은 광화 1 기 중기의 후반기에 정출이 시작되었 으며, 주로 괴상의 황동석 균열부 및 입자 사이 틈을 충 진하여 산출한다. 부분적으로 섬아연석, 비사면동석 및 사면동석을 교대하거나 균열부를 따라 충진하여 복합적 인 공생관계를 이루며 산출한다. 일부 방연석은 괴상의 황동석을 교대함과 동시에 함 비스무스 광물인 아이키나 이트로 교대되거나 용리조직을 보이며 밀접한 공생관계 를 이루어 산출한다. 대부분의 방연석은 비교적 광화후 기의 초기에 산출되며, 부분적으로 괴상의 산출 양상을 보여준다.

광화 2 기: 광화 2기는 주 광화작용이 진행된 이후 함 금·은 및 금속 광화작용이 이루어지지 않은 방해석맥의 생성 시기이다. 광상 내 부분적으로 생성 관찰되는 광화 2 기 방해석맥은 주 광화작용이 진행된 광화 1 기 석영맥 을 절단하거나, 석영맥 내에 발달한 소규모 균열면을 충 진하여 산출한다.

\section{5. 유체포유물}

유체포유물 실험·연구는 금화광상 열수 맥상광체 내 광 화 1기 석영 시료를 대상으로 양면 연마박편을 제작하여 유체포유물에 대한 가열·냉각 실험을 수행하였다. 현미경 가열·냉각 실험은 충북대학교 광상학 실험실에 설치된 Linkam scientific Instruments의 THMS 600(TMS 93) Heating/Freezing stage를 이용하여 수행되었다. 유체포유 물에 대한 가열·냉각 실험 시에는 정확도를 높이기 위해 서 Haynes(1985)의 repeated freezing technique를 활용하 였으며, 가열실험에서 측정되는 균일화온도의 측정오차 는 $\pm 1.0^{\circ} \mathrm{C}$ 이다. 염농도는 냉각실험에서 측정되는 icemelting 온도와 $\mathrm{H}_{2} \mathrm{O}-\mathrm{NaCl}$ 계의 freezing-point depression(Potter et al., 1978)을 이용하여 구하였다. 냉각실험에서 측정되 는 ice-melting 온도의 측정오차는 $\pm 0.2^{\circ} \mathrm{C}$ 이다.

\section{1. 유체포유물 가열 및 냉각실험 결과}

금화광상에서 확인되는 유체포유물은 상온 $\left(20^{\circ} \mathrm{C}\right)$ 에서 의 상(phase)관계 및 균일화 특성 등에 의하여 3가지 유 형(type I: liqid-rich; type II: vapor-rich; type III: three phase, halite-bearing)의 $\mathrm{H}_{2} \mathrm{O}-\mathrm{NaCl}$ 계 유체포유물이 관찰 되었다(Fig. 5).

Type I 유체포유물(aqueous, liquid-rich)은 기상(vapor) 과 액상(aqueous liquid)으로 구성되며, 액상이 우세(약 60 vol. $\%$ 이상)하여 가열실험 시 액상으로 균일화되는 특 징을 갖는다.

Type II 유체포유물(aqueous, vapor-rich)은 type I 유
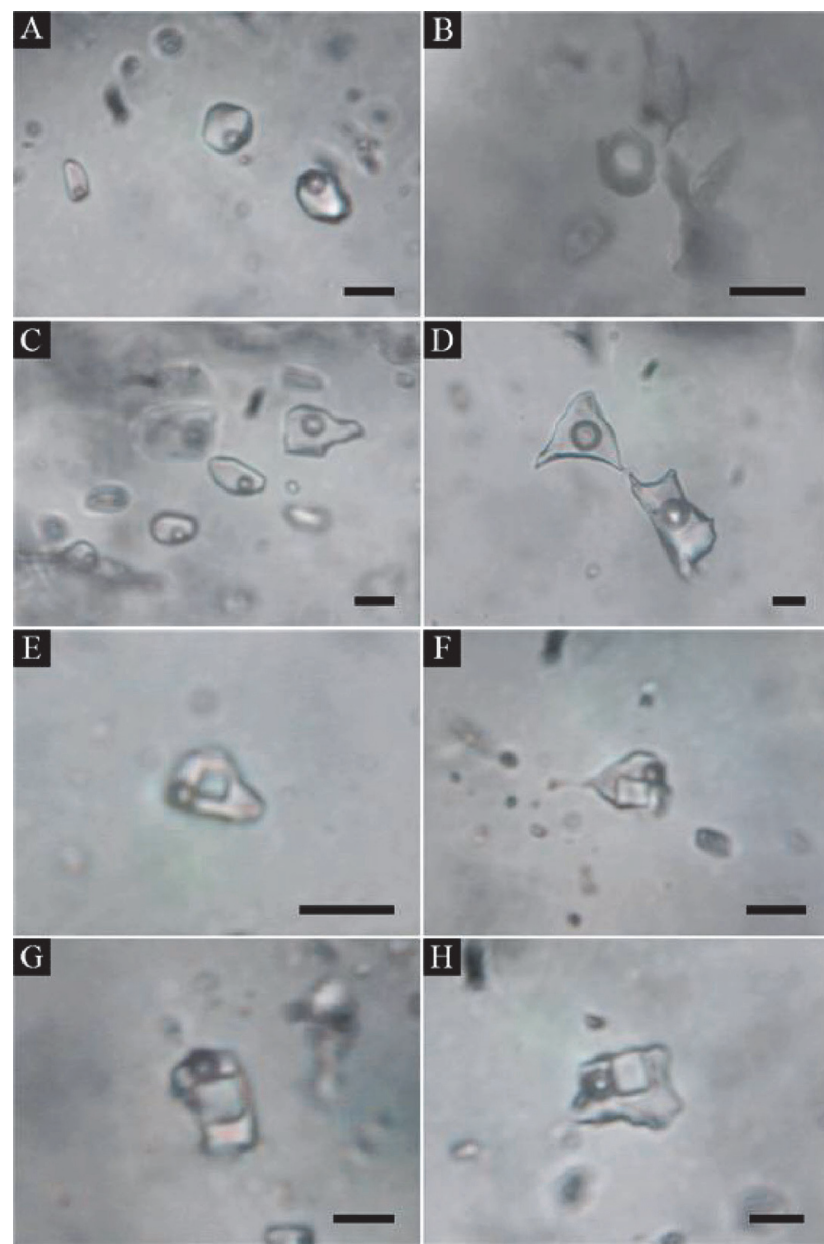

Fig. 5. Photomicrographs of type I (A, C, D), II (B) and III (E, $\mathrm{F}, \mathrm{G}, \mathrm{H})$ fluid inclusions in vein quartz, Geumhwa deposit.

체포유물과 같이 기상과 액상으로만 구성되나, 기상이 우 세(약 $60 \mathrm{vol} \%$ 이상)하여 가열실험 시 기상으로 균일화 되는 특징을 보여준다.

Type III 유체포유물(liquid+vapor+halite \pm other daughter minerals)은 기상(vapor)과 액상(aqueous liquid)으 로 구성된 유체포유물 내에 암염(halite) 결정이 산출되는 유형의 유체포유물이다. 유체포유물 내에 암염 결정이 산 출되는 열수의 진화 기작으로는 고염농도의 열수에서 이 미 결정화된 암염이 유체포유물 내에 포획되는 경우(type IIIa)와 일정 범위를 갖는 고염농도 열수가 유체포유물에 포획된 후 열수 냉각 과정에서 과포화되어 암염이 생성 되는 경우(type IIIb) 등이 있다.

금화광상의 유체포유물 균일화온도와 염농도는 매우 넓은 범위의 변화를 보여준다. 이는 금화 열수계에 다양 한 화학조성을 갖는 열수유체의 유입과 진화 특성이 반 영되어 균일화온도 및 염농도의 증감이 이루어진 것으로 해석된다. 


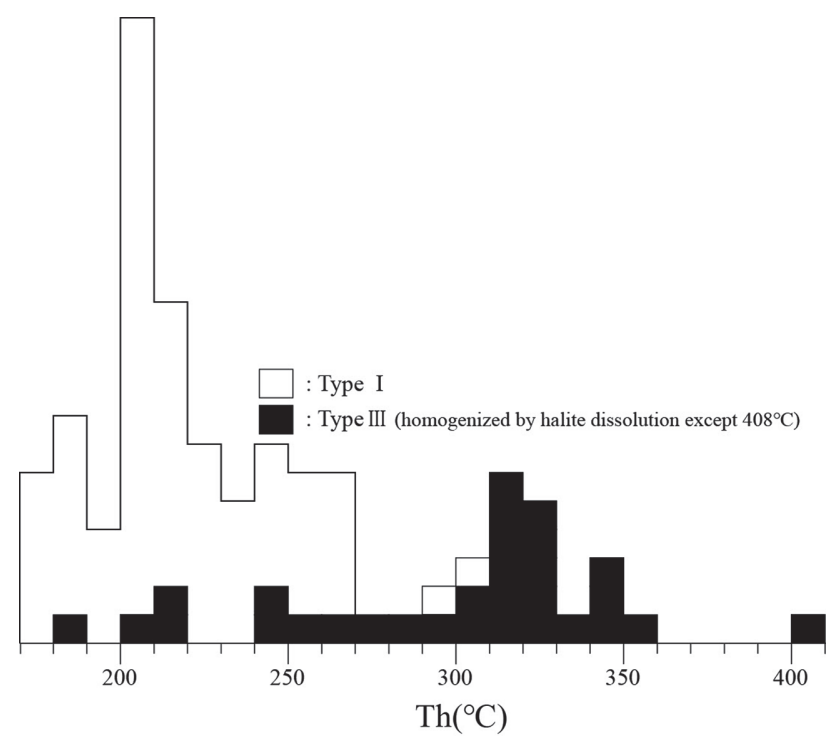

Fig. 6. Histogram of homogenization temperatures(Th) of fluid inclusions in vein quartz of the Geumhwa deposit.

Figures 6과 7은 금화광상 광화 1기 맥상 석영 내 유체 포유물 균일화온도와 염농도를 각각 도시한 것이다. 금 화광상의 광화작용 관련 맥상 석영 내 유체포유물은 $\approx 408^{\circ} \mathrm{C} \sim 171^{\circ} \mathrm{C}$ 의 넓은 온도 범위에서 균일화된다. 유체 포유물 중 type I 유체포유물은 $\approx 301^{\circ} \mathrm{C} \sim 171^{\circ} \mathrm{C}$ 의 온도 범위 에서 균일화되며, type III 유체포유물은 $\approx 408^{\circ} \mathrm{C} \sim 142^{\circ} \mathrm{C}$ 의 온도 범위에서 균일화된다. 이들 금화광상의 광화작용과 관련된 맥상 석영 내 유체포유물은 $\approx 43.4 \sim 0.7 \mathrm{wt} . \% \mathrm{NaCl}$ 상당 염농도를 보여준다. 금화광상의 맥상 석영 내 유체 포유물 중 type I 초생 유체포유물(primary fluid inclusions) 은 $\approx 12.0 \sim 0.7$ wt. $\% \mathrm{NaCl}$ 상당 염농도를 보여주며, type III 초생 유체포유물은 $\approx 43.4 \sim 30.9$ wt. \% NaCl 상당 염농도 를 보여준다. Type III 유체포유물의 경우, 암염의 용해온 도 $\left(\mathrm{Tm}_{\mathrm{NaCl}}{ }^{\circ} \mathrm{C}\right)$ 가 기상소멸온도 $\left(\mathrm{T}_{\mathrm{f}}^{\circ} \mathrm{C}\right)$ 보다 높아 최종 균일 화온도를 의미하는 type IIIa $\left(\mathrm{Tm}_{\mathrm{NaCl}}{ }^{\circ} \mathrm{C}: \approx 358^{\circ} \mathrm{C} \sim 180^{\circ} \mathrm{C}\right.$, $\left.\mathrm{T}_{\mathrm{f}}^{\circ} \mathrm{C}: \approx 315^{\circ} \mathrm{C} \sim 142^{\circ} \mathrm{C}\right)$ 와 기상소멸온도 $\left(\mathrm{T}_{\mathrm{f}}{ }^{\circ} \mathrm{C}\right)$ 가 암염용해 온도 $\left(\mathrm{Tm}_{\mathrm{NaCl}}{ }^{\circ} \mathrm{C}\right)$ 보다 높아 최종 균일화온도를 의미하는 type IIIb $\left(\mathrm{Tm}_{\mathrm{NaCl}}{ }^{\circ} \mathrm{C}: \approx 361^{\circ} \mathrm{C} \sim 191^{\circ} \mathrm{C}, \mathrm{T}_{\mathrm{f}}{ }^{\circ} \mathrm{C}: \approx 408^{\circ} \mathrm{C} \sim 251^{\circ} \mathrm{C}\right)$ 가 확인된다.

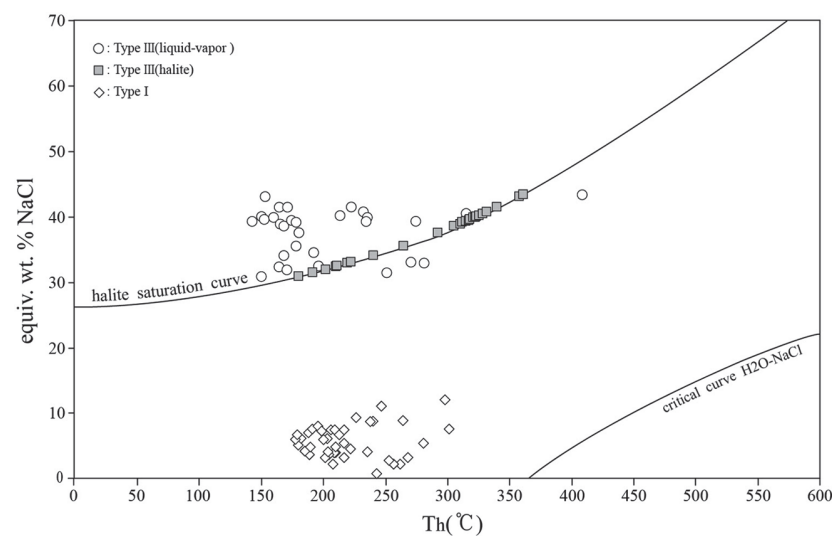

Fig. 8. Homogenization temperature versus salinity diagram for type I and III fluid inclusions in vein quartz of the Geumhwa deposit.

\section{2. 금화 열수계의 열수유체 진화특성}

유체포유물 가열 및 냉각실험 결과 확인되는 균일화온 도와 염농도 상관관계는 광석광물의 침전 메카니즘과 관 련된 열수계 광화유체의 진화특성을 반영하게 된다. 따 라서 이의 확인을 통하여 광상 내 주요 광석광물의 시공 간적 분포특성 등의 광화작용 특성을 규명할 수 있다.

Figure 8은 금화 함 금-은 열수광체의 광화작용을 야기 한 금화 열수계 광화유체의 진화 특성 규명을 위하여 본 광상 유체포유물 가열·냉각실험 결과를 균일화온도와 염 농도 상관도에 도시한 결과이다. 금화 열수계에는 고 염 농도의 유체와 중 내지 저 염농도의 유체 및 기상이 풍 부한 유체 등의 $\mathrm{H}_{2} \mathrm{O}-\mathrm{NaCl}$ 계 광화유체가 존재하였음이 확인된다.

금화 열수계 내 고 염농도의 유체의 존재를 의미하는 Type III 유체포유물은, 소수의 유체포유물(type IIIb)을 제외하면, 암염의 용해에 의하여 최종적으로 균일화되는 type IIIa 유체포유물에 해당한다. 이들 type IIIa 유체포유 물의 암염 용해온도는 $\approx 358^{\circ} \mathrm{C} \sim 180^{\circ} \mathrm{C}$ 로서 $\approx 43.1 \sim 30.9$ wt. \% $\mathrm{NaCl}$ 상당 염농도를 지시하며(Figs. 6, 7 and 8), 각각의 type IIIa 유체포유물 기상 소멸온도 $\left(\approx 315^{\circ} \mathrm{C} \sim 142^{\circ} \mathrm{C}\right)$ 보다 높다. 따라서 이들 유체포유물의 최종 균일화 온도인 암 염 용해온도는 유체포유물 생성온도가 아니며, 기상 소

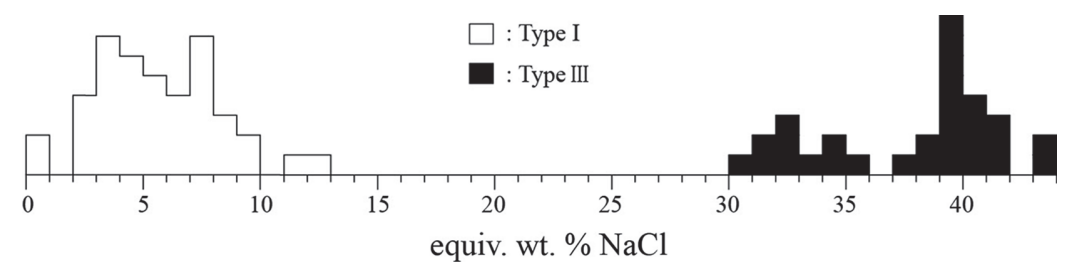

Fig. 7. Histogram of salinities of fluid inclusions in vein quartz of the Geumhwa deposit. 
멸온도인 $\approx 315^{\circ} \mathrm{C} \sim 142^{\circ} \mathrm{C}$ 의 온도 범위가 type IIIa 유체포 유물의 생성온도이다. 따라서 type IIIa 유체포유물은 고 염농도( $\geq 44$ wt. $\% \mathrm{NaCl}$ 상당 염농도)의 유체가 유입된 후 금화 열수계의 온도 감소와 비등작용 등에 수반되어 과포화가 이루어져 암염 결정이 생성된 후에 형성되는 유체포유물(생성온도 $\approx 315^{\circ} \mathrm{C} \sim 142^{\circ} \mathrm{C}$ ) 내에 포획된 것이다.

금화광상의 맥상 석영 내 유체포유물 중 type I 초생 유체포유물(primary fluid inclusions)은 $\approx 12.0 \sim 0.7$ wt. \% $\mathrm{NaCl}$ 상당 염농도를 보여주어 중 내지 저 염농도 유체의 존재를 지시한다. 또한, 유체포유물 크기 문제로 가열·냉 각실험이 진행되지 못한 type II 유체포유물이 관찰되는 점은 비교적 초기 열수계 내에서 비등(boiling)작용이 진 행되었음을 지시한다.

초기 금화 열수계에 유입된 고 염농도 유체와 중 내지 저 염농도 유체는 염농도 차이에 의한 비중 대비(density contrast)와 점도 차이 등에 의하여 분리되어 진화하게 된 다(Turner et al., 1970). 따라서 초기 금화 열수계는 하부 마그마로부터 용리된 유체와 금화광상 생성 심도 하부까 지 순환하여 물-암석 반응이 진행된 천수기원의 열수가 함께 유입되어 형성되었다.

금화광상의 유체포유물 실험·연구 결과를 종합하면, 초 기 금화 열수계는 $\geq 410^{\circ} \mathrm{C}$ 온도 조건에서 고 염농도 $(\geq$ 44 wt. $\% \mathrm{NaCl}$ 상당 염농도)를 갖는 유체와 $\approx 7.0$ wt. \% $\mathrm{NaCl}$ 상당 염농도를 보여주는 중 내지 저 염농도의 유체 가 함께 유입되어 형성되었으며, 그 이후 유체의 냉각, 비등(boiling)작용 및 천수 혼입(meteoric water mixing) 등에 의하여 진화되었으며, 이들 진화기구에 수반된 냉 각 작용 및 화학성 변화 등에 의하여 온도 감소 $\left(\leq 200^{\circ} \mathrm{C}\right)$ 와 염농도 변화 $(\leq 1.0$ equiv. wt. $\% \mathrm{NaCl})$ 가 야기되었다.

이러한 금화 열수계의 형성 및 진화 특성은 함 금-은(-동) 열수 맥상광상인 금화광상이 반암형으로 부터 천열수형 으로 변환되는 점이적인 환경에서 생성된 맥상광상(veintype system transitional between porphyry- and epithermaltypes)임을 지시한다.

\section{6. 광석광물의 지화학적 생성환경}

금화광상의 광화유체 내의 환경변화를 규명하기 위하 여, 광석광물의 산출 특성과 공생관계 및 조성 특성 등 을 활용한 열역학적 해석을 진행하였다. 금화광상 주 광 화시기인 광화 1기 온도 및 황 분압(sulfur fugacity: $\mathrm{fS}_{2}$ ) 조건의 규명을 위하여 산출 광석광물의 공생관계 및 $\mathrm{Fe}-$ S계, Fe-Zn-S계(Scott and Barnes, 1971), Au-Ag-S계(Barton and Toulmin, 1964: Craig and Barton, 1973)의 조성 변 화를 활용하였으며, 그 결과는 Figure 9에 제시되어 있다.

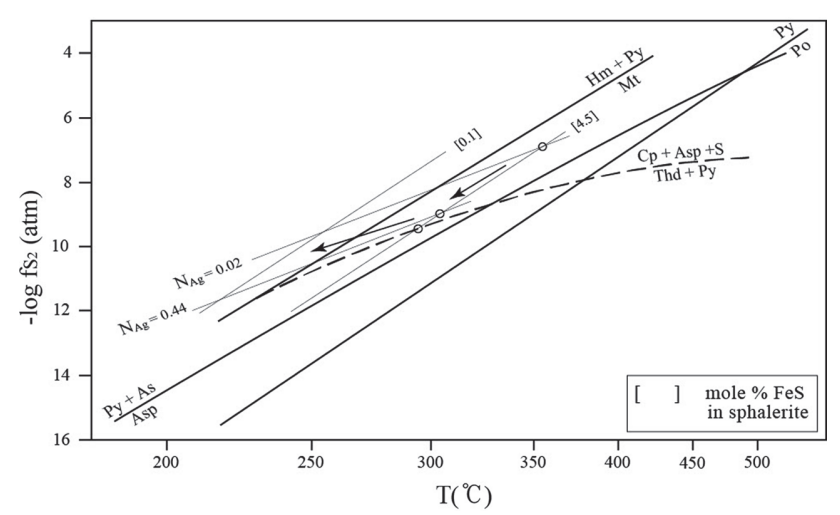

Fig. 9. Sulfur fugacity versus temperature diagram for stage I of Geumhwa Au-Ag deposit with sulfidation reactions. Abbreviations: As=arsenic, $\mathrm{Asp}=$ arsenopyrite, $\mathrm{Cp}=$ chalcopyrite, $\mathrm{Hm}=$ hematite, $\mathrm{Mt}=$ magnetite, $\mathrm{N}_{\mathrm{Ag}}=$ atomic fraction of $\mathrm{Ag}$ in electrum, $\mathrm{Py}=$ pyrite, $\mathrm{Po}=$ pyrrhotite, Thd $=$ tetrahedrite.

금화광상 주 광화시기인 광화 1 시기 초기에 산출하는 맥상 시료의 유체포유물 균일화온도와 황철석-에렉트럼자철석-섬아연석의 광물 조합 및 초기 내지 중기에 산출 하는 에렉트럼의 최대 화학조성( $\leq 98$ atomic \% Au)과 섬 아연석의 화학조성 $(\leq 4.5 \mathrm{~mole} \% \mathrm{FeS})$ 등을 활용한 초 기 광화작용 시 온도 조건은 $\approx 350^{\circ} \mathrm{C}$ 에서 $\approx 250^{\circ} \mathrm{C}$, 황 분 압 조건은 $\approx 10^{-7.0}$ 내지 $\approx 10^{-10.5} \mathrm{~atm}$ 이었다(Fig. 9). 주 광화 시기 중기에서 후기의 경우 광물조합(황철석-에렉트럼-섬 아연석 및 자철석 $\rightarrow$ 자철석-적철석 $\rightarrow$ 적철석)과 초기 내지 중기에 산출하는 에렉트럼의 화학조성(최소; $\approx 56$ atomic $\% \mathrm{Au}$ )과 섬아연석의 화학조성(최소; $\approx 0.1 \mathrm{~mole} \%$ $\mathrm{FeS}$ )을 이용하여 규명된 온도와 황 분압 조건은 각각 약 $300^{\circ} \mathrm{C} \sim 210^{\circ} \mathrm{C}, \approx 10^{-8.1} \sim 10^{-11.8}$ atm 이었다(Fig. 9).

금화 함 금-은 열수광체의 함 금-은 광물인 에렉트럼의 광화작용은 황철석(-황동석)-섬아연석 및 자철석 $\rightarrow$ 자철 석-적철석 $\rightarrow$ 적철석의 공생관계를 보이며 진행되었다 (Figs. 3 and 9).

금화 함 금-은 열수광체의 광화작용과 밀접한 수반관 계에 있는 맥상 석영에 대한 유체포유물 연구 결과 추정 된 금화 함 금-은 열수 광화작용은 초기 약 $400^{\circ} \mathrm{C}$ 의 온 도조건에서 시작되어 약 $130^{\circ} \mathrm{C}$ 에 걸쳐 진행되었다. 특히, 금화광체의 주된 함 금-은 광물인 에렉트럼의 침전은 주 로 금화열수계의 냉각작용과 부분적인 비등작용에 수반 되어 약 $300^{\circ} \mathrm{C}$ 의 온도조건의 열수로부터 시작되어 약 $180^{\circ} \mathrm{C}$ 에 걸쳐 진행되었다. 또한 열역학적 해석에 의한 온 도 및 황 분압 조건의 변화로 살펴본 함 금-은 광화작용 은 약 $350^{\circ} \mathrm{C}$ 내지 약 $210^{\circ} \mathrm{C}$ 에 걸쳐 진행되었다(Fig. 9).

이러한 금화 함 금-은 열수계 광화작용의 온도조건과 에렉트럼 및 수반 금속광물의 공생관계를 이용하여 산소 


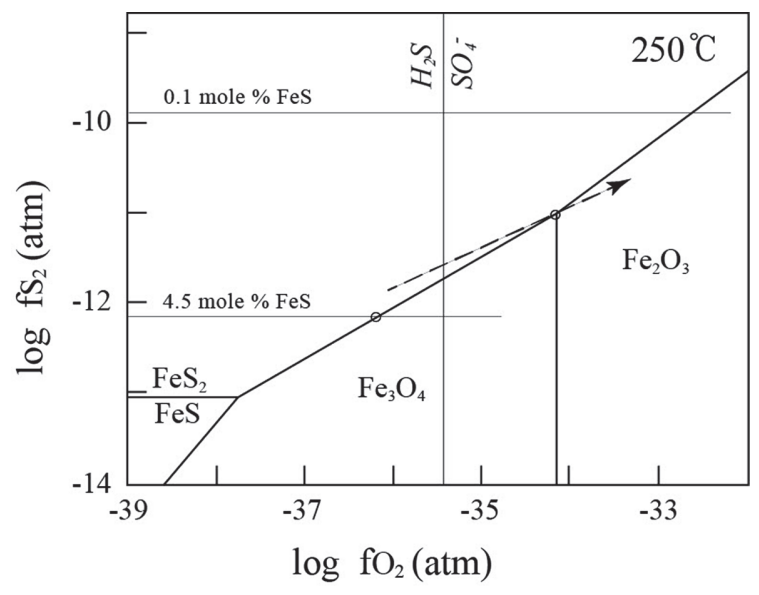

Fig. 10. $\log f \mathrm{O}_{2}-f_{\mathrm{S}_{2}}$ diagram calculated at $250^{\circ} \mathrm{C}$ showing stability relationship of the late main $\mathrm{Au}-\mathrm{Ag}$ mineralization temperature at Geumhwa deposit. The ranges in $f_{\mathrm{S}_{2}}$ were calculated from the FeS contents in sphalerite (Scott and Barnes, 1971) and mineral assemblages.

분압 조건의 변화와 광화작용과의 상관관계를 살펴보기 위하여 금화 함 금-은 열수 광체의 주 광화 관련 온도 조 건인 $250^{\circ} \mathrm{C}$ 조건에서의 상평형을 이용한 산소분압 조건 의 변화를 해석하였다(Fig. 10).

금화 열수광체에서의 주된 함 금-은 광물인 에렉트럼 의 주 광화시기 온도인 $250^{\circ} \mathrm{C}$ 의 경우 $\mathrm{Fe}-\mathrm{S}, \mathrm{Fe}-\mathrm{Zn}-\mathrm{S}$ 및 $\mathrm{Fe}-\mathrm{O}-\mathrm{S}$ 계 등을 이용하여 해석할 수 있다(Barton and Toulmin, 1964; Shikazono, 1986; Scott and Barnes, 1971). 즉 에렉 트럼의 주 광화시기 초기의 황철석(-황동석)-섬아연석-자 철석의 공생관계와 섬아연석의 화학조성 $(\leq 4.5 \mathrm{~mole} \%$ $\mathrm{FeS}$ )에 의하여 확인된 황 분압조건은 $\geq 10^{-12.2} \mathrm{~atm}$, 산소 분압조건은 $\approx 10^{-36.2} \mathrm{~atm}$ 이었다(Fig. 10). 에렉트럼의 주 광화 시기 중·후기의 황철석(-황동석)-섬아연석-자철석-적철석 및 적철석의 공생관계와 섬아연석의 화학조성 $(\geq 0.1 \mathrm{~mole} \%$ $\mathrm{FeS}$ )에 의하여 확인된 황 분압조건은 $\geq 10^{-11.0} \mathrm{~atm}$, 산소 분압조건은 $\geq 10^{-34.1} \mathrm{~atm}$ 이었다(Fig. 10).

금화광상 열수계의 온도와 황 분압조건은 광화작용의 진행과 함께 감소하며, 산소 분압조건은 크게 증가하는 변화 양상을 보여준다(Figs. 9 and 10). 이러한 금화 열수 계의 산화환경으로의 변화는 열수계 내 금 복합체의 용 해도 감소를 유도하여 에레트럼의 침전을 야기하였으며, 광화작용의 진행과 함께 주 광화시기 후기로 가면서 에 렉트럼과 함께 자철석 $\rightarrow$ 자철석-적철석 $\rightarrow$ 적철석의 공 생관계를 보여주는 광석광물의 침전이 야기되었다.

\section{7. 결 론}

금화광상은 괴상 및 호상조직과 함께 부분적인 각력상
및 정동의 발달 등 복성맥의 특성을 보여주는 함 금-은 석영 및 방해석 맥상 광체이다. 광물학적 연구와 유체포 유물 연구에 의하여 도출된 결과에 의하면, 금화 열수계 는 초기, 하부 마그마로부터 용리된 유체와 금화광상 생 성 심도 하부까지 순환하여 물-암석 반응이 진행된 천수 기원의 열수가 함께 유입되어 형성되었다. 즉, $\geq 410^{\circ} \mathrm{C}$ 온도 조건에서 고염농도( $\geq 44 \mathrm{wt} \% \mathrm{NaCl}$ 상당 염농도) 를 갖는 유체와 $\approx 7.0 \mathrm{wt} \% \mathrm{NaCl}$ 상당 염농도를 보여주 는 중 내지 저 염농도의 유체가 함께 유입된 이후 금화 열수계 유체의 냉각, 비등(boiling)작용 및 천수 혼입 (meteoric water mixing) 등에 의하여 진화되었으며, 이들 진화기구에 수반되는 냉각작용과 화학성 변화에 의하여 온도 감소 $\left(\leq 200^{\circ} \mathrm{C}\right)$ 와 염농도 변화 $(\leq 1.0$ equiv. wt. $\%$ $\mathrm{NaCl}$ ) 등이 야기되었다. 금화광상의 주된 금·은 광화작용 은약 $350^{\circ} \mathrm{C} \sim 210^{\circ} \mathrm{C}$ 의 온도 조건에서 열수계의 온도 감 소와 이에 수반된 부분적인 비등현상에 의하여 진행되었 다. 이때의 황 분압 조건은 $\approx 10^{-8.1} \sim 10^{-11.8} \mathrm{~atm}$ 이었다. 주된 함 금-은 광물인 에렉트럼의 주 광화시기 온도인 $250^{\circ} \mathrm{C}$ 의 경우 황 분압조건은 $\geq 10^{-11.0} \mathrm{~atm}$ 내지 $\geq 10^{-12.2} \mathrm{~atm}$, 산 소 분압조건은 $\geq 10^{-34.1} \mathrm{~atm}$ 내지 $\approx 10^{-36.2} \mathrm{~atm}$ 이었다.

금화광상 열수계의 온도와 황 분압조건은 광화작용의 진행과 함께 감소하며, 산소 분압조건은 크게 증가하는 산화 환경으로의 변화 양상을 보여준다. 즉, 광화작용의 진행과 함께 주 광화시기 후기로 가면서 에렉트럼과 함 께 자철석 $\rightarrow$ 자철석-적철석 $\rightarrow$ 적철석의 공생관계를 보 여주는 광석광물의 침전이 야기되었다.

이러한 금화광상의 광상.광물학적 특성, 지화학적 환경 변화 및 열수계의 형성과 진화 특성 등은 함 금-은 열수 맥상광상인 금화광상이 초기 천부 관입 마그마의 영향으 로 마그마 우세 열수계로 부터 광화 후기 천수의 유입이 우세해지는 천열수계로 변환되는 점이적인 생성환경에서 생성된 맥상광상임을 지시한다.

\section{사 사}

본 연구는 한국광물자원공사의 2019년 정밀조사 학술 연구용역의 지원을 받아 수행되었습니다. 현장 광상 조 사 시에 함께하여 도움을 주신 한국광물자원공사 탐사팀 팀원들에게 감사의 마음을 전한다. 본 논문을 세심하게 검토하여 고견을 주신 익명의 심사자들께 진심으로 감사 드린다.

\section{References}

Barton, P.B., Jr. and Toulmin, P., III. (1964) The electrum-tarnish 
method for the determination of the fugacity of sulfur in laboratory sulfide systems. Geochim. Cosmochim. Acta, v.28, p.619-640.

Chang, K. H. (1975) Cretaceous stratigraphy of South Korea. J. Geol. Soc. Korea, v.11, p.1-23.

Cho, D.L. and Kwon S.T. (1994) Hornblende geobarometry of the Mesozoic granitoids in south Korea and the evolution of crustal thickness. J. Geol. Soc. Korea, v.30, p.41-61.

Choe, W.H. and Jwa, Y.J. (2004) Petrological and geochemical evidences for magma mixing in the Palgongsan pluton. Geosciences Journal, v.8, p.343-354.

Craig, J.R. and Barton, P.B. Jr (1973) Thermochemical approximations for sulfosalts, Econ. Geol., v.68, p.498-506.

Haynes, F.M. (1985) Determination of fluid inclusion compositions by sequential freezing. Econ. Geol., v.80, p.1436-1439.

Hong, Y.K. (1983) Petrology and geochemistry of the Cretaceous Palgongsan granite, Southern Korea. J. Geol. Soc. Korea, v.16, p.83-109.

Kang, H.C. and Paik, I.S. (2012) Review on the geological ages of the formations in the Gyeongsang Basin, Korea. J. Geol. Soc. Korea, v.49, p.17-29.
Kim, B.G., Jung, C.H., Kim, S.J. and Yang, S.Y. (1981) Geological report of the Dae Yul sheet (1:50.000), p.41.

Lee, H.G., Moon, H.S. and Choi, S.G. (2007) Economic mineral deposits in Korea, Acanet, Seoul, 762p.

Potter, R.W. III., Clunne, M.A. and Brown, D.L. (1978) Freezing point depression aqueous sodium sodium chloride solutions. Econ. Geol., v.73, p.284-285.

Scott, S.D. and Barnes, H.L. (1971) Sphalerite geothermometry and geobarometry. Econ. Geol., v.66, p.653-669.

Shelton. K.L., So, C.S. and Chang, J.S. (1988) Gold-rich mesothermal vein deposits of the republic of Korea: Geochemical studies of the Jungwon gold area. Econ. Geol., v.83, p.1221-1237.

Shikazono, N. (1986) $\mathrm{Ag} / \mathrm{Au}$ total production ratio and $\mathrm{Au}-\mathrm{Ag}$ minerals from vein-type and disseminated-type deposits in Japan. Mining Geol., v.36, p.411-424.

Tsusue, A., Mizuta, T., Watanabe, M. and Min, K.G. (1981) Jurassic and Cretaceous granitic tocks in South Korea. Mining Geol., v.31, p.260-280.

Turner, J.S., Shirtcliffe, T.G.L. and Brewer, P.G. (1970) Elemental variations of transport coefficients across density interfaces in multiple-diffusive system. Nature, v.228, p.1083-1084. 